Review: Central Asia

Author(s): W. Broadfoot

Review by: W. Broadfoot

Source: The Geographical Journal, Vol. 31, No. 1 (Jan., 1908), pp. 92-93

Published by: geographicalj

Stable URL: http://www.jstor.org/stable/1777264

Accessed: 26-06-2016 20:27 UTC

Your use of the JSTOR archive indicates your acceptance of the Terms \& Conditions of Use, available at

http://about.jstor.org/terms

JSTOR is a not-for-profit service that helps scholars, researchers, and students discover, use, and build upon a wide range of content in a trusted digital archive. We use information technology and tools to increase productivity and facilitate new forms of scholarship. For more information about JSTOR, please contact support@jstor.org.

The Royal Geographical Society (with the Institute of British Geographers), Wiley are collaborating with JSTOR to digitize, preserve and extend access to The Geographical Journal 
In his volume on the Kumbum monastery-the first of the special monographs on the results of the journey-Lieut. Filchner gives the most complete account that has yet appeared of its present condition and its history. The other volume above referred to describes the zoological and botanical collections.

\section{Central Asia.}

' In the Footsteps of Marco Polo: Being the Account of a Journey Overland from Simla to Pekin.' By Major C. D. Bruce, late Commanding the Chinese Regiment of Infantry. Edinburgh and London: William Blackwood \& Sons. 1907.

This interesting description of a long and, in places, rough journey deserves and we hope will obtain, considerable popularity, for it appeals to all sorts and conditions of men. To geographers because, as often as was possible, an untrodden or little-known route was selected, and the countries visited from the desert of Takla Makan onward have at present, for such persons, special interest. History readers will find much information respecting Buddhism; Chinese intercourse with India, Tibet, and Turkistan ; and the ancient history of China. Others more interested in the present than in the past, will find a great coalfield in Kansu described. Baron von Richthofen has said that it was one of the most remarkable in the world, but had two great disadvantages: distance from the sea or navigable rivers, and being situated a few thousand feet above the adjoining plain. English enterprise, if not thwarted by Chinese prejudice and obstruction, might surely be equal to finding a profitable solution.

Again, that strange deposit, so interesting to students of physical geography, known as the loess formation, was met, and a long description of it by Baron v. Richthofen is quoted. The relations between the three empires chiefly concerned in Central Asia, the policy followed, and other matters, are touched on with commendable restraint. In this volume, therefore, there is no want of food to suit many tastes.

Major Bruce makes some sound remarks on the religion of Ladákh; he says, "The Ladakis who inhabit this country differ considerably from the Kashmiris. The former profess Buddhism, but, be it said at once, a form which bears hardly any resemblance to the elerating and mystic faith which Buddha once taught.

"The actual religion of Ladak is a modified form of Indian Buddhism, and was introduced more than two thousand years ago. It is contained in a voluminous work called the ' Kah-Gyur,' or 'Translation of Precepts,' because it is a version of the precepts of 'Sakya' made from the Indian language."

He gives further particulars, and mentions a mission from Leh to Lhasa "known as the Lapchack Mission." It is of old standing, and is sent every third year, and was payment of tribute as well as a commercial enterprise. Now the British authorities consider it has no political signification, but that view is probably not held by the Tibetan rulers, who regard it as nazar, or tribute. The distinction, as matters now stand, is unimportant, but if ordinary advantage had been taken of the Younghusband mission, the British Government would have been, sooner or later, the protecting power; thus at the same time assuming superiority, and, through Kashmir, paying tribute; a situation savouring of comic opera.

The journey of Major Bruce's party may be divided into three main parts : from Simla to the Tibetan frontier at the top of the Lanak pass, Chang Chenmo valley; thence viâ Kiria to Su-chau, the first town met in China proper; and from Su-chau to Peking. The first part calls for no special notice, but there is much interest at present felt in the second part. For not only is the question of the battle between the sunds of the desert and the water from the snows involved, but recent archæological research, chiefly under Dr. M. Aurel Stein, happily still in progress, has 
brought to light many manuscripts and relics which are expected to throw light on matters more or less obscure. Of the boundaries of this tract the major says, "The geographical area commonly known as Chinese Turkestan is a somewhat vague one. By some geographers it is considered to embrace the larger portion of the western extra-mural Chinese Empire. By others the area so described is confined to the basins drained by the streams which run into Lopnor, as well as by those which lose themselves in the great central desert, the Takla Makan.

"From the Chinese point of view the latter are more nearly correct, the territory being always known to the people of that vast empire as the Hsing Chiang, or new frontier."

Whilst travelling along the southern side of the Takla Makan some sport, of which there is an animated description, was had ab ut Nia, and the fact of passing to the south of the terminal lake of the combined waters from both sides of the desert has led to remarks on the Lob-nor controversy. That is, we hope, practically set at rest by the explanation that the lake is and was a changing and migrating body of water, and that now, not improbably, it is returning to the old site, as shown in ancient Chinese records.*

In instances the names in the text do not agree with those in the maps, in which Umrutsi is found for Urumtsi ; but on the whole the book is fairly free from misprints, and is well turned out.

W. BROADFOOT.

\section{A Detch Voxage in the Persian Gulf.}

'Cornelis Cornelisz Roobacker's Scheeps-Journaal, Gamron-Basra (1645); de eerste Reis der Nederlanders door de Perzische Golf.' Edited by A. Hotz. Leiden: Brill. 1907.

In 1645 Wollebrandt Geleynsz de Jongh, the President of the Dutch factories in Persia, decided to follow the example of the English in establishing a factory at Basra. Two small ships-the Delfshaven and the Schelvisch-were accordingly despatched with a cargo of merchandise under the charge of Dirck Sarcerius. They sailed towards the end of June, reached their destination a month later, and landed their merchants, who, having obtained favourable terms from the Turkish governor, started their factory with every prospect of success. The Delfshaven sailed on her return voyage in September, and anchored at Gombroon on October 5. Her master, Cornelis Roobacker, had, of course, kept a careful journal of the voyagethe first undertaken by the Dutch in the Persian gulf-and this has now been printed by the Royal Geographical Society of the Netherlands. The original is missing, but use has been made of a transcript which was carried home by Geleynsz, and after his death passed, with others of his papers, into the possession of the municipal authority of Alkmaar, his birthplace. From their custody it was last year transferred to the Rijksarchief at the Hague.

The journal itself is of the usual character-a terse, straightforward narrative of the voyage, with special stress on matters relating to navigation. It has been admirably annotated by the editor, Mr. A. Hotz, who has also provided a copious and learned introduction, with a full list of books and maps dealing with the Persian Gulf and its trade. A special feature is the reproduction in facsimile of a contemporary chart of the Gulf-possibly by Roobacker himself-which is now in the library of Leiden University.

W. F.

* Geogr. Journal, vol. 27, p. 610. 